\title{
New species and records of Chimarra Stephens (Trichoptera, Philopotamidae) from Central Amazonia, Brazil ${ }^{1}$
}

\author{
Allan Paulo Moreira Santos ${ }^{2,3}$ \& Jorge Luiz Nessimian ${ }^{2,4}$
}

${ }^{1}$ Publication number 12 of the Igarapés Project.

${ }^{2}$ Departamento de Zoologia, Instituto de Biologia, Universidade Federal do Rio de Janeiro, Caixa Postal 68044, Cidade Universitária, $21944-970$ Rio de Janeiro-RJ, Brasil. a.santos@ufrj.br; nessimia@acd.ufrj.br

\begin{abstract}
New species and records of Chimarra Stephens (Trichoptera, Philopotamidae) from Central Amazonia, Brazil. Chimarra (Curgia) paucispina sp. nov., of the aurivittata group Flint, 1998 is described and illustrated from specimens collected in Amazonas State. The key to species of Chimarra (Curgia) Walker, 1860 presented by Flint was modified to include the new species. Chimarra (Chimarrita) chela Blahnik, 1997 and Chimarra (Curgia) jugescens Flint, 1998 are for first time reported for the Amazonas State. This is the first record of C. chela in Brazil.
\end{abstract}

KEYWORDS. Amazon Basin; Curgia; new species; Philopotamidae; Trichoptera.

RESUMO. Nova espécie e registros de Chimarra Stephens (Trichoptera, Philopotamidae) da Amazônia Central, Brasil. Chimarra (Curgia) paucispina sp. nov., do grupo aurivittata Flint, 1998 é descrita e figurada a partir de exemplares provenientes do Estado do Amazonas. A chave para as espécies de Chimarra (Curgia) Walker, 1860 apresentada por Flint foi modificada para inclusão da nova espécie. Chimarra (Chimarrita) chela Blahnik, 1997 e Chimarra (Curgia) jugescens Flint, 1998 são pela primeira vez registradas para o Estado do Amazonas, sendo também o primeiro registro de C. chela para o Brasil.

PALAVRAS-CHAVE. Bacia Amazônica; Curgia; nova espécie; Philopotamidae; Trichoptera.

Three genera are recognized in the subfamily Chimarrinae: Chimarra Stephens, 1829, Chimarrhodella Lestage, 1925, and the monotypic and poorly known genus Edidiehlia Malicky, 1993 (Blahnik 2004). Chimarra is the largest genus in the family Philopotamidae, and one of the largest genera in the order Trichoptera (Blahnik 1997). The genus is found in all regions of the world, but seems to be much more diverse in warmer tropical and subtropical areas (Flint et al. 1999). Phryganea marginata Linnaeus, 1767 was described from Sweden and later transferred to the new established genus Chimarra by Stephens, becoming the type species of the genus (Flint 1998). Walker (1860) described the first Neotropical species of Chimarra, as Curgia braconoides Walker, 1860. Recent taxonomic revisions of Chimarra (Blahnik 1997, 1998, 2002; Flint 1998) defined accurately the subgenera Chimarra and Curgia Walker, 1860, and two other subgenera, Chimarrita Blahnik, 1997 and Otarrha Blahnik, 2002, were erected.

Currently, 92 species are recognized in the subgenus Curgia, with distribution ranging from the southwestern United States through Central America and much of South America. In Brazil, 40 species of Chimarra are recorded, 26 in the subgenus Curgia. Based on material collected in the Central Amazonia, a new species of Chimarra (Curgia) is here described. Chimarra (Curgia) jugescens Flint, 1998 and Chimarra (Chimarrita) chela Blahnik, 1997 are newly recorded for the Amazonas State, and this is also the first report of $C$. chela in Brazil.

The types are deposited in the entomological collection of the Instituto Nacional de Pesquisas da Amazônia, Manaus, Brazil (INPA).

\section{Chimarra (Curgia) paucispina sp. nov.} (Figs. 1-6)

Male. Forewing length $5.5 \mathrm{~mm}$. Wing venation typical for subgenus (Figs. 1 and 2). General color (in alcohol), including wings, dark brown. Setal warts on dorsum of the head with setae pale brown. Legs pale brown, with spurs dark brown. Abdomen brown dorsally and pale ventrally.

Male Genitalia. Eighth tergum with posterior margin projecting as a large lobe, in dorsal aspect with a deep, Ushaped mesal incision (Fig. 3). Ninth sternum with a thin median longitudinal keel on the posterior third (Fig. 4). Tenth tergum broad basally, narrowing to the apex, in dorsal aspect with a deep, U-shaped mesal incision, with scattered sensillae (Fig. 3). Preanal appendages small and ovoid. Inferior appendages elongate, in ventral aspect, fused mesally for basal third, internal apical area flattened dorsoventrally with margin forming a right angle, apicolateral process spatulate anteroposteriorly and strongly curved inwards, with rounded apex (Fig. 5). Phallus tubular, short and inflated basally, internally with phallotremal sclerite as a ring-like structure with a small ventral rod, and with seven dark spines (Fig. 6).

Female. Unknown.

Material. Holotype male: BRAZIL, Amazonas State, Manaus. 



Figs. 1-6. Chimarra paucispina sp. nov. 1, forewing; 2, hindwing; 3, eighth, ninth, and tenth terga and preanal appendages, dorsal; 4, male genitalia, lateral; 5, inferior appendages, ventral; 6, phallus, lateral.

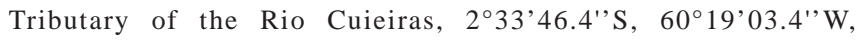
22.viii.2004, J.L. Nessimian \& L. Fidelis (INPA). Paratype: same data as holotype, 1 male (INPA).

Etymology. From the Latin pauci ("few”) and spina ("spine"), in allusion to the few number of dark spines present in the phallus.

The new species belongs to the aurivittata group Flint, 1998, with Chimarra aurivittata Flint, 1971 and C.jugescens Flint, 1998. This group is characterized by the presence of a bright orange spot on the forewings, the fusion of the inferior appendages and the mesal division of the eighth and tenth terga. Material preserved in alcohol usually loses the setae, discharacterizing the pattern of coloration. The specimens here described are preserved in alcohol and it is not possible to identify the original color pattern, but the new species shows characteristics of the aurivittata group, e.g. eighth and tenth terga with mesal incision and fused inferior appendages. The three species occur in the Central Amazonia, Brazil, and they can be distinguished only by male genitalia. In Chimarra paucispina sp. nov. the inferior appendages are more elongate, fused only in the basal third, with apicolateral process strongly curved inwards and spatulate anteroposteriorly, and the phallus bears fewer internal spines (12-18 in C. aurivittata and 26-29 in C. jugescens).

The entry to aurivittata group in the key to species of Chimarra (Curgia) presented by Flint (1998) was modified to include the new species, as below.

1. Forewing with a large, circular golden spot centrally (still not confirmed in the new species); inferior appendages in ventral aspect fused mesally or fused for basal third (aurivittata group)...2 
2. Inferior appendages in ventral aspect broadly fused mesally C. aurivittata

Inferior appendages only fused for basal third of length .. 3

3. Inferior appendages with apicolateral process caliper-like; phallus with 26 to 29 short, dark spines ...... C. jugescens

Inferior appendages with apicolateral process spatulated, strongly curved inwards and rounded apex; phallus with seven dark spines C. paucispina sp. nov.

\section{New records of Chimarra}

Chimarra (Chimarrita) chela Blahnik, 1997

Two specimens of Chimarra (Chimarrita) chela (male and female) were collected in the Amazonas State. This is the first record of $C$. chela in Brazil, previously reported only to Venezuela (Blahnik 1997).

Material. BRAZIL, Amazonas State, Manaus. Tributary of the Rio Branquinho, 2²9'35.1'’S, 60²0’03.1' W, 26.viii.2004, J.L. Nessimian \& L. Fidelis, 1 female (INPA); tributary of the Rio Cuieiras, $2^{\circ} 42^{\prime} 25.1^{\prime \prime} S$, $60^{\circ} 22^{\prime} 28.2^{\prime \prime} \mathrm{W}, 19 . v$ iii.2004, J.L. Nessimian \& L. Fidelis, 1 male (INPA).

Chimarra (Curgia) jugescens Flint, 1998

A male of Chimarra (Curgia) jugescens was collected in Amazonas State. C. jugescens was reported to Para State, Brazil (Flint 1998), now it is recorded to Amazonas State, Brazil.
Material. BRAZIL, Amazonas State, Rio Preto da Eva. Rio Preto da Eva, 2`32’09.4"S, 5949’59.3"W, 20.viii.2004, J.L. Nessimian, 1 male (INPA).

Acknowledgements. The authors thank A. M. Sanseverino for the manuscript revision and useful comments. This study was supported by Fapeam, Fundação O Boticario and CNPq. Capes and CNPq provided fellowships, respectively to the first and the second authors. This is contribution \# 12 of Projeto Igarapés.

\section{REFERENCES}

Blahnik, R. J. 1997. Systematics of Chimarrita, a new subgenus of Chimarra (Trichoptera: Philopotamidae). Systematic Entomology 22: 199-243.

Blahnik, R. J. 1998. A revision of the Neotropical species of the genus Chimarra, subgenus Chimarra (Trichoptera: Philopotamidae). Memoirs of the American Entomological Institute 59: vi+1318 .

Blahnik, R. J. 2002. Systematics of Otarrha, a new Neotropical subgenus of Chimarra (Trichoptera: Philopotamidae). Systematic Entomology 27: 65-130.

Blahnik, R. J. 2004. New species of Chimarrhodella from Venezuela and Ecuador (Trichoptera: Philopotamidae). Zootaxa 552: 1-7.

Flint Jr., O. S. 1998. Studies of Neotropical caddisflies, LIII: a taxonomic revision of the subgenus Curgia of the genus Chimarra (Trichoptera: Philopotamidae). Smithsonian Contributions to Zoology 594: 1-131.

Flint Jr., O. S.; R. W. Holzenthal \& S. C. Harris. 1999. Catalog of the Neotropical Caddisflies (Insecta: Trichoptera). Columbus, Ohio Biological Survey, vi+239 p.

Walker, F. 1860. Characters of Undescribed Neuroptera in the Collection of W.W. Saunders, Esq., F.R.S., etc. Transactions of the Entomological Society of London 5: 176-199. 